\title{
Beloved Things: Interpreting Curated Pottery in Diasporic Contexts
}

\author{
Shannon Cowell ${ }^{1}$ (D) $\cdot$ Kelly Jenks ${ }^{2}$
}

Accepted: 16 September 2020 / Published online: 9 October 2020

(C) Springer Science+Business Media, LLC, part of Springer Nature 2020

\begin{abstract}
Historical archaeologists often view curated or heirloom pottery as a frustrating anomaly in the dating of historical-period sites or contexts. Fewer pause to consider why the artifacts were curated in the first place, or what their presence reveals about the people who maintained them. Drawing on a case study of curated micaceous pottery at a Hispanic diaspora site in east-central New Mexico, this article argues that investigation of heirloom pottery can offer insights into the functional, familial, and cultural significance of these beloved things.

Keywords Curation · Diaspora · Identity · Ceramics · New Mexico

"Her work was constant - preparing meals, always piles of tortillas on the table, a pot of beans bubbling on the stove, the aroma of home....” Rudolfo Anaya (2020:xiv)
\end{abstract}

\section{Introduction}

Historical archaeologists often view curated or heirloom ceramics with irritation rather than interest because of the way they complicate the relative dating of historical-period sites. Stanley South (1977:207) acknowledged the likelihood of recovering "a few heirloom pieces" of pottery in collections from sites and sought to account for them

Shannon Cowell

scowell@archaeologysouthwest.org

Kelly Jenks

kljenks@nmsu.edu

1 Archaeology Southwest, 300 North Ash Alley, Tucson, AZ 85701, USA

2 New Mexico State University, P.O. Box 30001, MSC 3BV, Las Cruces, NM 88003, USA 
through the development of his mean ceramic dating formula. Subsequent generations of archaeologists have argued over whether ceramics are even useful for dating sites, in part because of their relatively long use-lives and the greater likelihood of recovering heirloom or hand-me-down items (e.g., Adams 2003; Williamson 2006). Yet, while historical archaeologists often mention heirloom ceramics in the context of archaeological dating, few pause to ask why these artifacts were curated or what their presence reveals about the people who maintained them. In this article, we consider these questions in our analysis of curated micaceous cookpot fragments recovered from a late nineteenth/early twentieth-century Hispanic diaspora community in east-central New Mexico. Through this analysis, we argue that the investigation of heirloom pottery can offer new insights into the functional, familial, and cultural significance of these beloved things.

\section{Materiality, Migration, and Inherited Objects}

Anthropologists have long been interested in what things reveal about the people who make, exchange, use, and discard them. Marcel Mauss (1954) considered how reciprocal gift exchanges function to create and maintain social relationships in so-called traditional societies. A generation of anthropologists inspired by Karl Marx focused on the commodification of things within capitalist societies, considering its many social and political consequences. In his landmark edited volume The Social Life of Things, Arjun Appadurai (1986) questioned the tendency of scholars to dichotomize gifts and commodities, encouraging researchers instead to consider the varied social relationships that are revealed when focusing on the objects rather than the subjects who make and exchange them. Igor Kopytoff (1986), writing in the same volume, argued that commodification is a process that is best understood by taking a biographical approach to the study of objects. Tracking a single object throughout its lifespan allows one to understand how the same item can be made into a generalized, impersonal commodity or a singular, inalienable thing at different points in time, and may hold different values and meanings simultaneously when viewed by different people. As an example of the latter, Kopytoff (1986:80) notes that a jeweler would likely view his watch as just another commodity, even though Kopytoff inherited this object from his father and it is, to him, a precious heirloom.

For the purpose of the current study, we are less interested in exploring the early history of the micaceous pots as commodities - their production and trade - than we are in understanding why they became heirlooms and what it means that they were kept and curated. The English anthropologist Daniel Miller (who began his career in archaeology) describes materiality as a theoretical perspective that attempts to understand people's ideas, values, and relationships through the lens of material culture. As he says, "an anthropologist does not start from individuals who create their worlds. We start from the historical processes and material order which create those characteristic individuals and their expectations. In short, material culture matters because objects create subjects much more than the other way around" (Miller 2008:287). Miller draws on Pierre Bourdieu's $(1973,1977)$ notion that our daily practices express and reinforce our underlying values, noting that material objects play a significant role in this process because they are so often routine and unseen, allowing them to "determine our 
expectations by setting the scene and ensuring normative behavior, without being open to challenge" (Miller 2005:5). In this way, everyday items like cooking pots can be significant, even if the people who used them may not have thought so, because they shaped those people's domestic environments, cooking practices, and cuisine in ways that subconsciously shaped and reinforced their social and cultural identities.

The micaceous pots that are the focus of this study were nonlocal objects transported to the site by Hispanic New Mexicans who ventured beyond their traditional homeland, defined by Spanish and Mexican land grant communities, to take advantage of new American homestead laws. While still technically within their home country, they were effectively immigrants in this new place, adapting to an alien legal system, strange neighbors, and a landscape with which they were not intimately familiar. Migration disrupts the pattern of everyday life, often fracturing what Bourdieu (1977) refers to as doxa - a set of unquestioned and implicit ideas about the order of the natural and social world. In this moment of crisis, migrants may find their attention drawn to everyday objects and practices and the comfort they provide. Implicit ideas and identities that were embodied through these daily practices now become explicit, as migrants seek to redefine themselves in a new setting by consciously engaging with familiar objects and/ or performing familiar tasks. Archaeologist Magdalena Naum (2012:93) describes it this way: "If certain routines and artifacts are salvaged in this situation, they may receive a new meaning transcending the ordinariness of the everyday. They may become a point of anchorage for immigrants in their novel environments, ways of expressing identities, and at the same time they may act as reminders of the past."

This shift in the significance of everyday objects and practices among migrants is described in many contemporary studies of migration, diasporas, and material culture (e.g., Miller 2008; Parkin 1999; Tolia-Kelly 2004). Theano Moussouri and Eleni Vomvyla (2015:98) consider the significance of items "from home" possessed by Albanian immigrants in Greece, observing that these objects and photographs "acquire prominent status as touchstones of cultural and biographical narratives enacting embodied, sensory connections with sites, sounds, environments, textures, and landscapes of enfranchisement and belonging." These sensory connections to familiar places and better times help them cope with the social "exclusion and stigmatization" (Moussouri and Vomvyla 2015:105) that is often part of the immigrant experience. Objects relating to food often hold particular significance, as the preparation and consumption of these foods evoke many senses at once. Elia Petridou (2001) describes how Greek students in England solicit care packages of food from home and prepare them for friends in an effort to evoke feelings of home and belonging in a natural and cultural landscape that feels utterly foreign. As she says, "Home becomes a steady point of reference in the search for meaning, a starting point for the journey of self-creation. Food serves this purpose by providing the sense of stability and continuity of the idealized home" (Petridou 2001:102). Closer to our study area, Raquel Rubio-Goldsmith (1998) describes how Mexican women immigrants to the United States in the early twentieth century sought comfort and control over their new environments through the traditional domestic task of creating and maintaining gardens seeded with familiar vegetables, herbs, and flowers. Forced to deal with the shift from being part of the conquering (Spanish) population in Mexico to becoming part of a conquered and disparaged (Mexican) population in the United States, these women "built their [garden] walls and within re-created their own version of "civilization"” (Rubio-Goldsmith 1998:283). 
Familiar, everyday objects and practices not only help anchor migrants as they adapt to new places, they also help them maintain their sense of connection to people left behind. As Miller (2008:286) says, "People exist for us in and through their material presence," thus material objects are an integral part of all social relationships. RubioGoldsmith (1994:141) notes that Mexican women migrated to the United States with seeds for their gardens, and explains that seeds like these were "passed from mother to daughter from time immemorial." Thus, a squash or a rose planted in the garden was more than just a simple plant - it was a living expression of the relationship between mother and daughter, between home and homeland. These and other memories kept women attached to their gardens - the place where a stillborn child was buried, the tree planted by a son later killed in war, the countless ways that relationships with family were embedded in places, plants, and things.

Sociologist Helen Holmes (2018) argues that a significant but understudied aspect of families is the active role that everyday material objects play in reproducing and sustaining kinship. She employs a performative definition of family as something that we $d o$, and observes that one of the key ways that we perform our familial relationships is by passing on objects. By focusing on these objects and the contexts of their use, Holmes identifies four types of "material affinities": 1) inherited mundane objects in use, 2) handed down objects, 3) repurposed objects, and 4) objects as family reminders. The first category of objects have some sentimental value but are more often valued for practical reasons; nevertheless, the physical act of using these items serves as a routine reminder of the current owner's familial ties with the (deceased) previous owner. The second category comprises items that are handed down between living kin, which likewise provide opportunities to remember, perform, and reinforce kin ties. The third category, repurposed objects, consists of upcycled items handed down from family members. While these are "not treasured keepsakes to be preserved without change" (Holmes 2018:11), part of their value is sentimental because they evoke the relationship between the current and original owners. Finally, the last category consists of curated objects valued for their associations with family-for example, a set of porcelain received as a wedding gift or a grown child's former favorite toy. By focusing on family through the lens of inherited or curated objects, Holmes (2018:6) shows how "kinship can be layered within everyday objects, and their sentimental value realized and celebrated through their use."

While Holmes describes how inherited objects can help maintain relationships between the living and recently deceased, Lin Foxhall (2012) argues that objects can also create and sustain emotional ties in the absence of face-to-face relationships. Foxhall offers a modern example of a wooden spoon inherited from her grandmother's sister, a woman who died before Foxhall was born. Despite never meeting her, she came to know and admire her great aunt through her grandmother's stories and through the object - the spoon - that held and evoked these memories and affectionate feelings. Her daughters, in turn, never met their great-grandmother but likewise came to know and feel connected to these women through the stories connected with this spoon. Foxhall (2012) then considers the emotional significance of loom weights in ancient Greece - artifacts that young women inherited, used, and brought with them after marriage as they moved in with their husband's family (also see Tarlow 2012:174). Drawing on historical and archaeological evidence, Foxhall (2012) argues persuasively that these seemingly banal artifacts could become charged with emotion and through 
these objects these sentiments could transcend time, connecting women to distant or deceased kin in the same way that her daughters felt connected with their maternal lineage through a shared wooden spoon.

Finally, while material objects (artifacts) have social and cultural value, they have practical value as well. In writing about contemporary theories of materiality and object agency, Lars Fogelin (2019:123) reminds archaeologists to also consider "how the specific materiality of an object shapes its agency and the social implications of that agency." Not all objects are equally likely to be transported to new places or passed down among family members. Likewise, not all imported or inherited objects are equally likely to be kept, used, and valued. Utilitarian objects of the kind described by Foxhall (2012) and captured in Holmes' (2018) inherited mundane objects in use are valued primarily for their utility, and it is through the everyday use of these objects that people's relationships with family, culture, or homeland are performed. Thus, in considering the micaceous utility ware fragments that are the focus of this study, it is important to consider not just those relationships, but also the performance characteristics of the pots themselves that enabled and encouraged their continued use.

\section{Case Study}

In 2014, Kelly Jenks directed field school students in documentation, surface collection, and test excavation activities at the site of Los Ojitos, located in the Middle Pecos River Valley in east-central New Mexico (Jenks et al. 2017). This rural community was first settled by Hispanic homesteaders in the late 1860s and abandoned less than a century later after dam construction downstream threatened the floodplain. Archaeological fieldwork targeted the village core, which includes remnants of the earliest homesteads, the cemetery, and several of the springs (ojitos) that gave the community its name. Surface collection and excavation produced 9,221 artifacts and ecofacts consisting mostly of metal, glass, and ceramics. Over $90 \%$ of the ceramic fragments derive from American- or English-manufactured serving and cooking vessels that were commonplace in the area during the late nineteenth and early twentieth centuries. Six percent of the fragments derive from micaceous earthenware cooking pots that were produced, traded, and used by Hispanic and Native American women in northern New Mexico, especially during the late eighteenth and nineteenth centuries (Cowell 2018). These micaceous pots, which appear to have been brought to Los Ojitos by the earliest settlers and maintained over several generations, are the focus of this case study.

\section{Los Ojitos and the Hispanic New Mexican Diaspora}

The Spanish conquered and colonized New Mexico in 1598, establishing a series of settlements along the Rio Grande that would form the core of New Mexico's "Hispano homeland" (Frank 2000; Meinig 1971; Nostrand 1992; Rodríguez 1992; Van Ness 1991). After centuries of Hispanic political dominance, these lands were conquered by American forces in 1846 and administered as an American Territory following the end of the Mexican-American War. Despite promises by the United States to honor the property rights of former Mexican citizens, American land speculators targeted and eventually acquired lands held in common by Hispanic communities (Ebright 1994). 
After 1862, Hispanic New Mexicans sought to recoup their losses by using the Homestead Acts to settle and claim parcels of public land. In seeking these new lands, many Hispanic families left their home communities and ventured down the Pecos River and out toward the plains, where they encountered and competed with white American settlers locally known as "Anglos." The rural community of Los Ojitos was established by some of these Hispanic homesteaders along a stretch of the Middle Pecos River in this Hispano-Anglo borderland (Fig. 1).

Urban segregation, especially in New Mexican towns and cities established by Anglos, peaked in 1900 with highly clustered racialized settlement (Nostrand

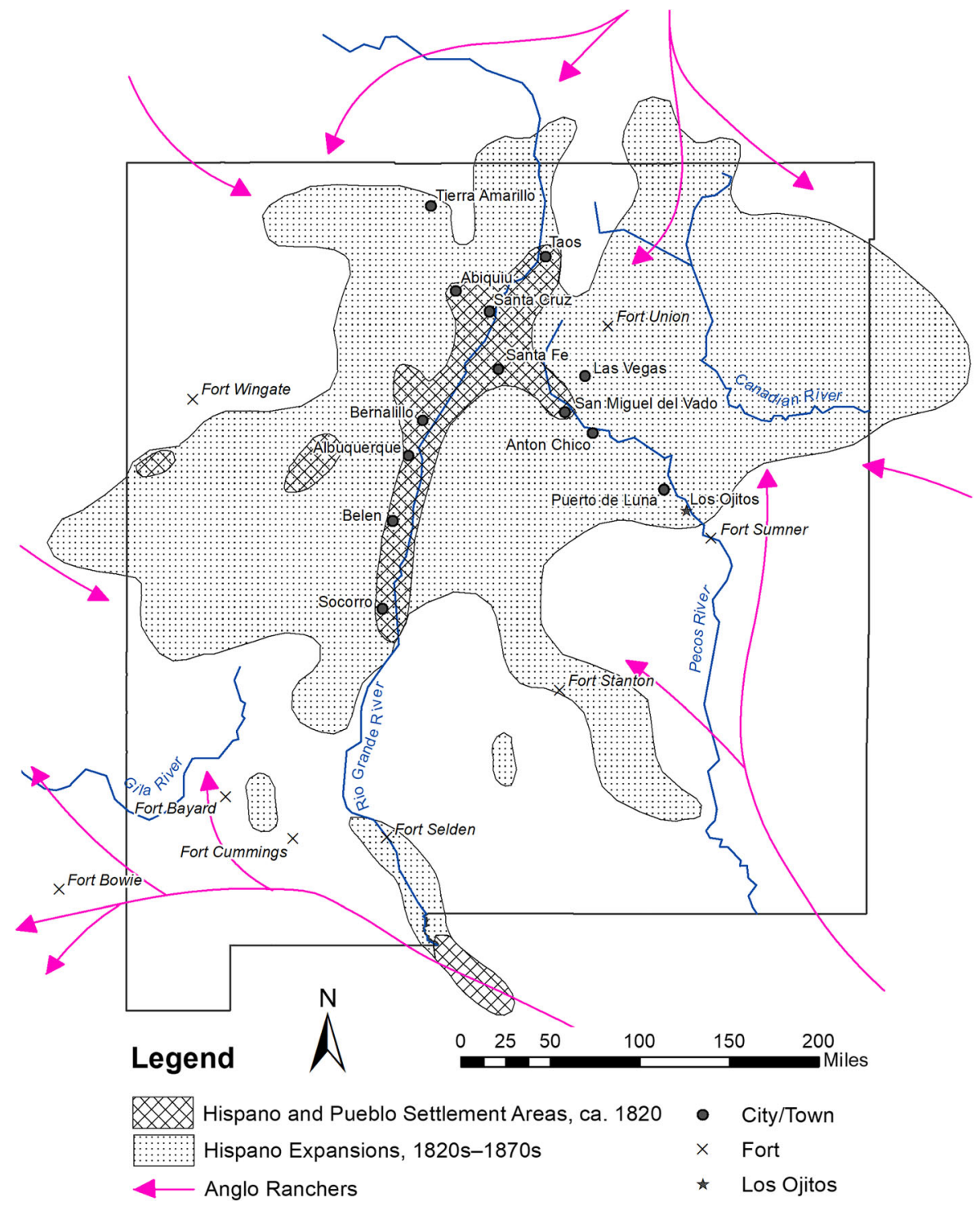

Fig. 1 Map of Hispano and Anglo expansion in Ne d modified from Meinig 1971:fig. 4-1. 
1992:205-211). Rural communities in New Mexico were similarly segregated along ethnic and racial lines. Los Ojitos, which reached a peak population of 287 residents within 53 families in 1910 (Jenks et al. 2017:12), was a predominately Hispanic community. More than $90 \%$ of all residents were native New Mexicans of Hispanic descent, and Spanish was the only language spoken by most residents throughout the village's history. The residents maintained a traditional mixed economy, farming the river valley and grazing livestock on the surrounding plains; in census records, most heads of household self-identified as day laborers, farmers, ranchers, or sheep or cattle herders. Most, if not all, of the residents were practicing Catholics - in contrast to the predominately Protestant Anglo immigrants - and evidence of their faith is recorded on petroglyphs, tombstones, and in religious medallions and artifacts observed in or collected from the site (Jenks et al. 2017; Jenks 2019). Residents who attended church would have traveled to Puerto de Luna, a majority-Hispanic town located about $18 \mathrm{mi}$ $(29 \mathrm{~km})$ upstream, which was the epicenter of religion and commerce for the area's rural Hispanic communities (del Fierro Duran 2018:74-76; O'Mack 2006). After 1903, when the Rock Island and El Paso railroad was built through Santa Rosa, the commercial center shifted north to that Hispanic-majority town (O'Mack 2006). In contrast, Fort Sumner - a town located about $23 \mathrm{mi}(37 \mathrm{~km})$ downstream from Los Ojitos, and with stronger connections to the Anglo community - played a less central role in that village's history (Jenks et al. 2017:11; O'Mack 2006). Thus, while residents of Los Ojitos lived far from the nucleated center of the "Hispano homeland" (Meinig 1971; Nostrand 1992), they maintained close economic, religious, and social ties to the Hispanic New Mexican community (del Fierro Duran 2018:74-76; Jenks et al. 2017).

While Hispanic New Mexicans were legally designated "free whites" by the United States in accordance with the Treaty of Guadalupe Hidalgo, they experienced considerable racial prejudice under American rule (Clark 2005, 2011; Rodríguez 1992). Throughout the fight for New Mexican statehood and self-government in the late nineteenth and early twentieth centuries, many Americans characterized Hispanic New Mexicans as mixed-blood mestizos unfit for citizenship without the prerequisite whiteness (Mora 2011; Nieto-Phillips 2004:48). Hispanic identity thus came to be defined by this paradox between "the legal construction of Mexicans as racially 'white' alongside the social construction of Mexicans as non-white and as racially inferior" (Gómez 2007:4). The social and political marginalization of Hispanic New Mexicans within the state made them more reliant on each other for supportespecially at the margins of the Hispano homeland, where Anglo families equaled or even outnumbered Hispanic residents.

When the geopolitical border between the United States and Mexico "crossed" Hispanic New Mexicans, the legal practices of a new regime forced people from within the core territory of the Hispanic homeland into peripheral, less-familiar lands controlled by an antagonistic government. While the inhabitants of Los Ojitos were not immigrants in a strict sense of the word, as a newly subaltern population displaced by American land policy to the edge of their homeland and subjected to the encroachment of American people, norms, and goods, they likely experienced "diasporic forms of longing, memory, and (dis)identification" (Clifford 1994:304). This feeling among Hispanic New Mexicans is often described as "querencia" (e.g., Fonseca-Chávez et al. 2020), an old Spanish term for attraction or longing that has come to be associated specifically with the longing for homeland, or the "feeling of safety and belonging that 
a person has for a specific place" (Rodríguez 2017:199). This feeling of querencia - of longing for the Hispano homeland - remains powerful among the descendant community to this day; Sylvia Rodríguez (2017:195) writes, "at the heart of modern Nuevomexicano identity formation is the paradoxical condition of being simultaneously displaced and place-based."

\section{Micaceous Cook Pots as Heirlooms}

Residual micaceous clays found in the Sangre de Cristo Mountains in northern New Mexico have supplied potters with a durable medium for utilitarian cookpots for centuries. Sangre de Cristo Micaceous wares were produced throughout the Upper Rio Grande Valley by Pueblo, Jicarilla Apache, and Hispanic potters during the seventeenth, eighteenth, and early nineteenth centuries (Eiselt 2005; Eiselt and Ford 2007; Eiselt and Darling 2012). As a semi-nomadic group exclusively specializing in large micaceous vessel production, Jicarilla Apaches often set up ceramic production camps alongside Hispanic consumer villages in northern New Mexico and traded the finished vessels for food or other products from the village (Eiselt and Darling 2012:432). Large cooking pots, water jars, and serving bowls produced by Jicarilla Apache potters comprise the majority of micaceous ceramic assemblages analyzed from Hispanic village sites on the northern Rio Grande dating to the first half of the nineteenth century (Eiselt and Darling 2012:439).

American annexation of the Southwest in the mid-nineteenth century brought widesweeping material changes, disrupting local barter economies with new technologies and distribution patterns and ultimately leading to the abandonment of micaceous ceramic production and trade as a means of subsistence. While historical evidence points to continued production of micaceous ceramics into the $1850 \mathrm{~s}$ by a band of Jicarilla Apaches on the Upper Pecos River near San Miguel del Vado (Abel 1915:6, 1916:201-202; Bender 1974), decades of displacement and famine followed by forced removal to the Jicarilla Apache reservation in 1887 precludes the possibility that these potters traded with consumers at Los Ojitos (Anderson 1999; Rebolledo et al. 2000). This leaves only the possibility that micaceous pots obtained in trade in the Upper Pecos Valley during the mid-nineteenth century were brought by early settlers downstream to Los Ojitos (Cowell 2018).

Micaceous ceramic sherds were recovered from several contexts at Los Ojitos, including excavated deposits within three residential structures (numbers 2, 14, and 15) and in test units and surface refuse scatters surrounding structures 2 and 8 (Fig. 2). Macroscopic analysis confirmed that these fragments were Sangre de Cristo Micaceous wares, even though Los Ojitos is located outside of their typical distribution area (Cowell 2018). Although some Hispanic women on the Upper Pecos Riverparticularly those with close familial ties to Indigenous potters - may have produced their own pottery (Carrillo 1997), there is no archaeological evidence of pottery production at Los Ojitos. Instead, these vessels appear to have been brought to Los Ojitos by the Hispanic families who settled this site in the late nineteenth century.

Contextual clues indicate that these micaceous pots were curated and deposited decades after their arrival at Los Ojitos. A Cimarron Micaceous rim sherd, attributed to a vessel produced by Jicarilla Apache potters (likely before the 1880s), was recovered during excavations in Structure 15 alongside diagnostic artifacts dating 1900-40 


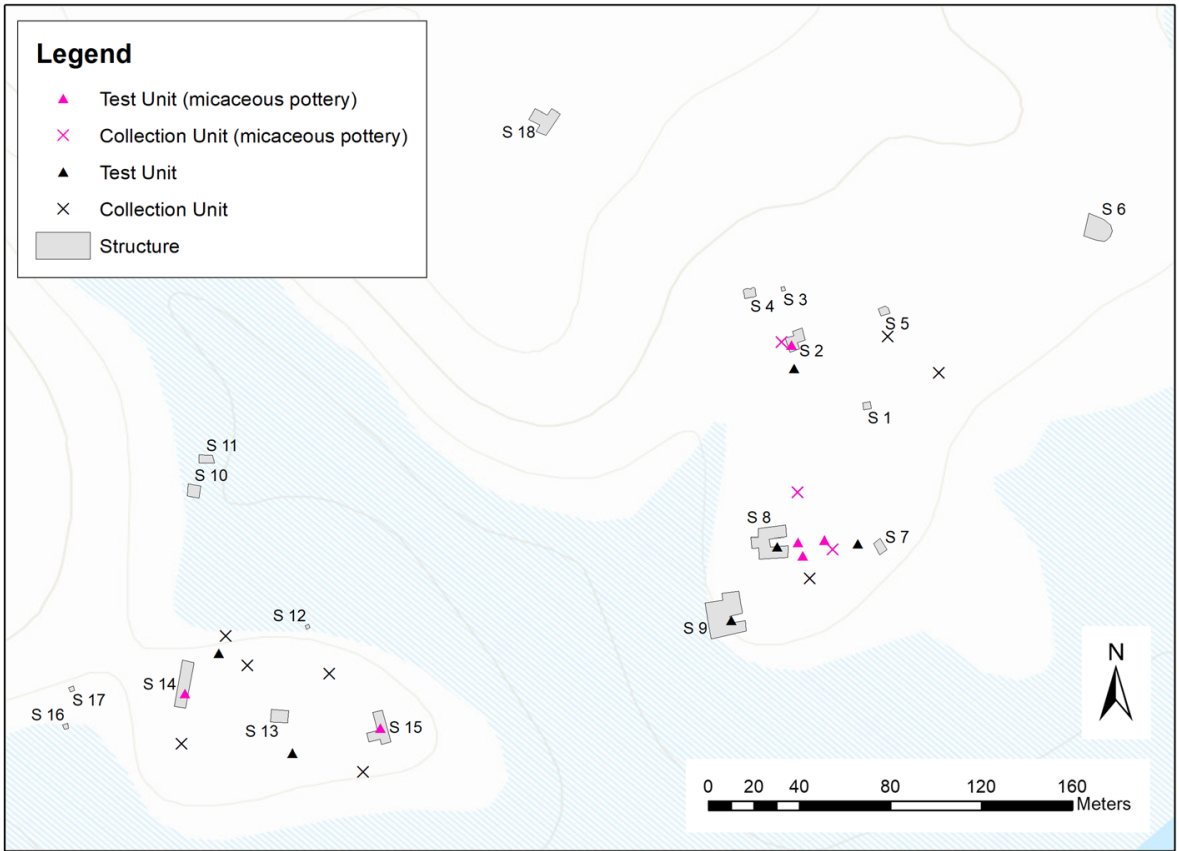

Fig. 2 Plan map of the site of Los Ojitos highlighting the test excavation and collection units that produced micaceous ceramics.

(Cowell 2018:109; Jenks et al. 2017:169). A concentration of Sangre de Cristo Micaceous jar sherds, including several painted with a red tempera paint (Fig. 3), was recovered from fill just above a hard-packed earthen floor in Structure 2 (Fig. 4), alongside mid-twentieth century artifacts such as a leather glove, part of a car engine mount, black plastic music record fragments, and a complete Vicks VapoRub jar dating between the 1910s and 1950s (Cowell 2018:100; Jenks et al. 2017:148-149). Another Sangre de Cristo sherd was recovered from a test unit placed over a traditional Hispanic adobe corner fireplace within Structure 14 (Fig. 5) in a room likely constructed after 1900 (Cowell 2018:107; Jenks et al. 2017:174). That these micaceous ceramic fragments were discarded alongside twentieth-century artifacts suggests that they were maintained and used for several decades - a long time for even the most durable utilitarian ceramics (Foster 1960:608).

These micaceous cooking pots were clearly quite rare on the Middle Pecos. Low frequencies of micaceous ceramics are found at Los Ojitos, both relative to sites within the traditional area of trade and relative to the frequencies of mass-produced American tableware sherds at the site. The first generations of Hispanic women who settled Los Ojitos from the late 1860s onward likely brought pots from the last generation of traditionally produced and traded micaceous ceramics from northern New Mexico. These ceramics would have been virtually impossible to replace on the spatial periphery of the Hispanic New Mexican homeland in the decades after Jicarilla Apaches were forcibly relocated to reservations. The maintenance of micaceous ceramics is a testament to the importance they held for the women of Los Ojitos: these vessels were preferentially preserved and curated over decades of use. 

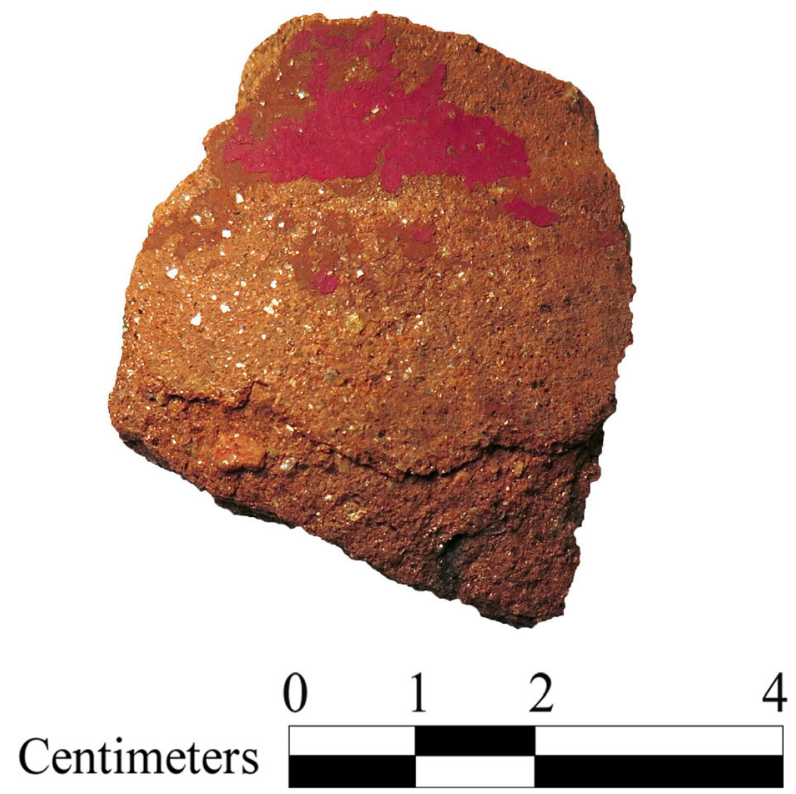

Fig. 3 Micaceous ceramic fragment painted with red tempera paint.

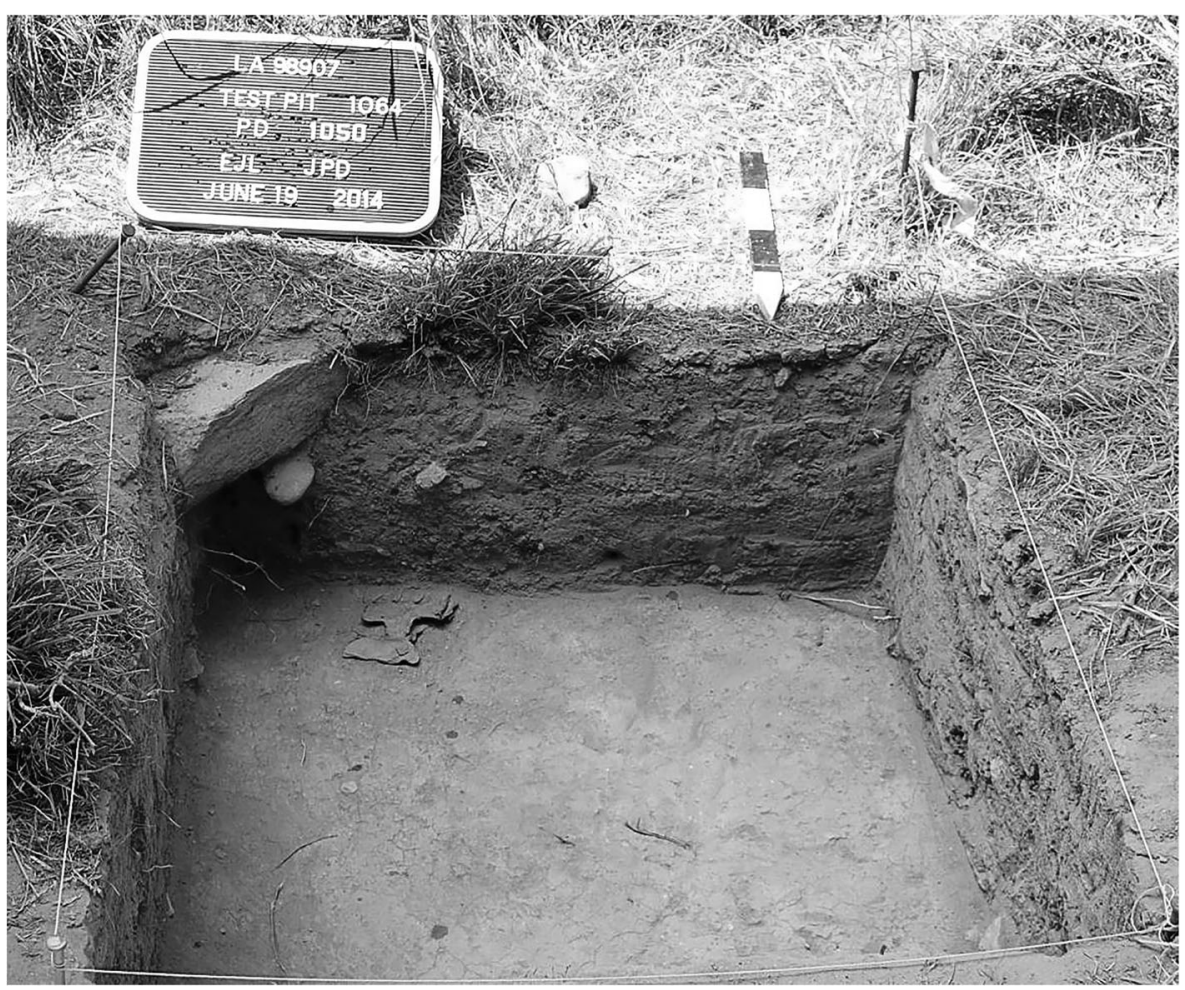

Fig. 4 Photograph of earthen floor uncovered in test excavations in Structure 2. Micaceous ceramics were recovered in the floor fill. 


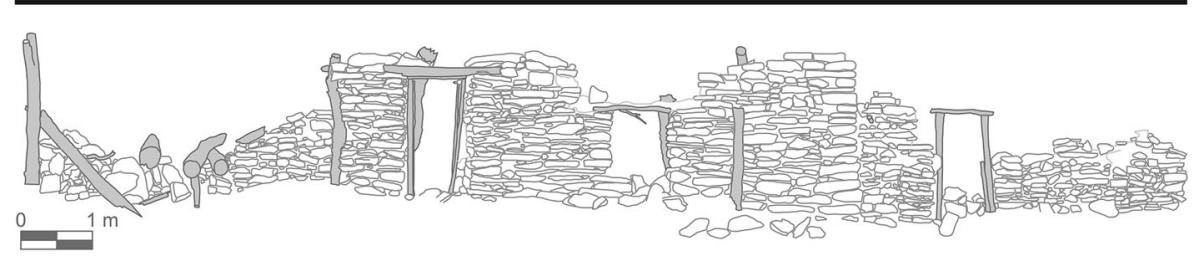

Fig. 5 Profile map of Structure 14. Micaceous ceramics were recovered from excavations within a hearth feature in the room on the left side.

\section{Why Do Micaceous Pots Matter?}

So, why do micaceous cookpots persist, appearing in late contexts at far-flung homesteads? American land practices and discrimination brought disruption to everyday Hispanic life, forcing adaptation to new legal realities and migration to peripheral borderlands. As Hispanic homesteaders packed their wagons and trekked down the Pecos, they faced a new social and economic paradigm, a new set of neighbors, and new ways of acquiring goods. A micaceous cookpot-formerly accepted as an everyday, replaceable tool and perhaps taken for granted - became, through the fracturing of Bourdieu's (1977) doxa, something irreplaceable, precious, and laden with cultural significance and memories of home. Unique material qualities inherent in these utilitarian micaceous pots - the earthy flavor they impart on foods, their glittering visual impact, and their literal construction from the earth of the homeland-made these tools particularly potent everyday reminders of past homes and hearths.

\section{Materiality}

Comments celebrating the superiority of micaceous bean pots are common in both historic and modern New Mexico, where these vessels are treasured by cooks and potters alike. To this day, New Mexican ceramic artists produce micaceous pottery for sale, using the distinctive taste it adds to cooked foods as a selling point. The late Felipe Ortega, a renowned Jicarilla Apache potter, considered micaceous pots to be an essential tool for making palatable beans: "the beans taste better!" (Anderson 1999:22). Artist Martha Romero (2017) of Nambé Pueblo described the special flavor imparted by micaceous cookware as earthy, mineral-rich, and appealing to "anyone who ate dirt as a child." The pores of micaceous pots hold onto flavor, and each dish prepared leaves a visual and aromatic residue that transfers flavors from the past into new meals during the process of cooking. These characteristics place micaceous ceramics in a category exclusive of other types of cookware- there are no substitutes in American cookware or local non-micaceous earthenwares. According to Duane Anderson (1999:7), "If micaceous pots were not so ideally suited for cooking, they probably would have disappeared, as many other varieties did, when metal pots and pans made their way into the Southwest on the Santa Fe Trail and later by way of the railroads."

The preeminence of micaceous bean pots lies in the physical qualities of the mica itself. Source materials identified in Eiselt's geochemical sourcing of historic northern Rio Grande micaceous ceramics came from the Vadito Group, a formation common to 
both the Sangre de Cristo and San Juan Mountains that contains fine residual clays with up to $80 \%$ residual muscovite content (Eiselt and Darling 2012). Mica's reputation in both historical and modern potting communities as a resilient and durable temper perfect for cookpots (Eiselt and Darling 2012; Warren 1981) is supported by West's (1992) experiments with various tempering materials. West (1992:67) suggests that the deliberate use of primary clays with wide aplastic size ranges and abundant aplastics in the Rio Grande region "appears to be purposeful with the objective of obtaining qualities of improved thermal shock resistance." This makes micaceous pots both durable and user-friendly, extending their longevity beyond the usual lifespan of an earthenware cookpot. Thus, like other objects in Holmes' (2018:7) category of inherited mundane objects in use, "these objects are kept because they keep working - they are good at what they do, therefore there is no need to replace them."

The methods used to cook with micaceous ceramics comprise part of a suite of culinary practices unique to New Mexico. Slow initial heating and low, sustained temperatures for up to six hours of cooking protect the pots from breakage and cook beans and other foods to perfection (Fig. 6). The persistence of these practices suggests adherence to a set of beliefs about what kinds of vessels are essential to the production of certain foods. In the mid-nineteenth century, as Hispanic families were beginning to migrate down the Pecos River, an American circuit judge commented on the ubiquity of these cookpots in New Mexico, writing, "They cook almost universally in earthen vessels, which bear the general name of tinaja, and it is a rare thing to see any other description of culinary articles" (Davis 1982 [1857]:179). Generations later, near the end of the Los Ojitos occupation, Fabiola Cabeza de Baca Gilbert (1982 [1949], 2013

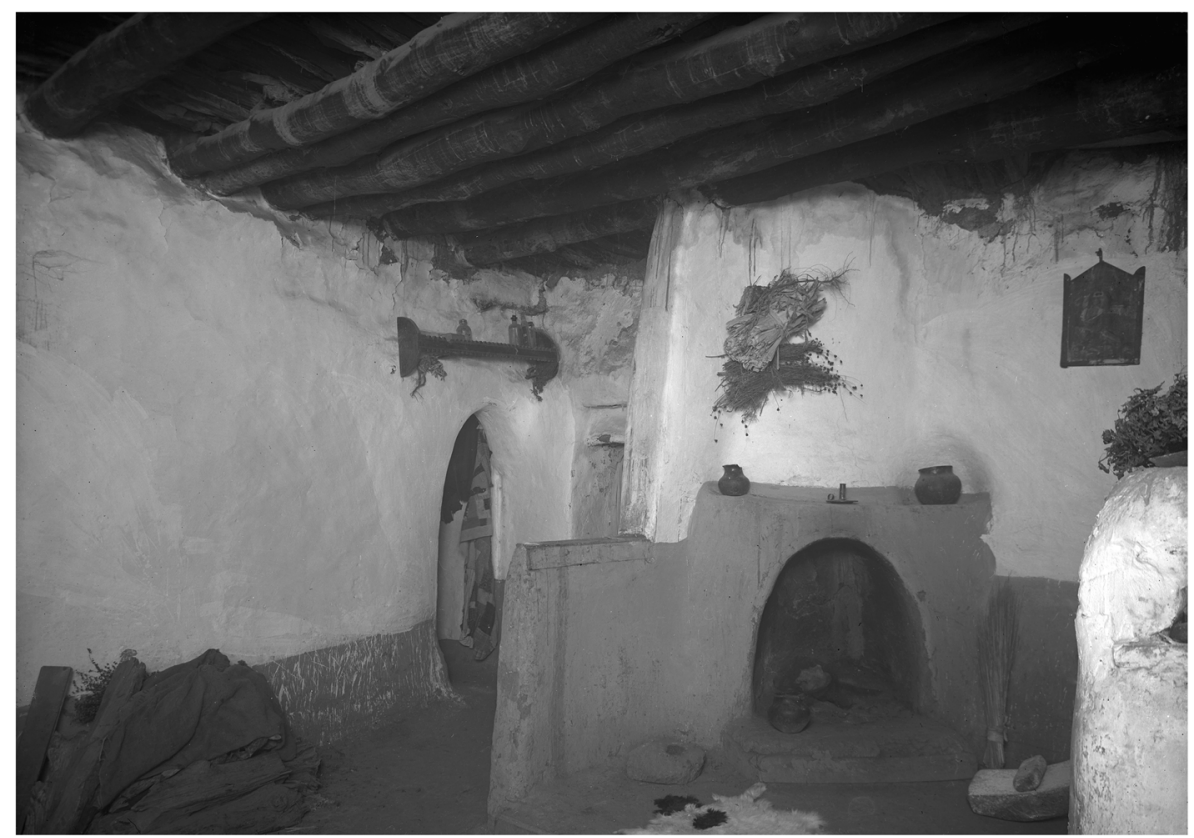

Fig. 6 Photograph taken in 1912 of the Applegate-de la Pena home in Santa Fe, New Mexico featuring earthenware cooking pots on the mantel and in the hearth. Photograph by Jesse L. Nusbaum, Courtesy Palace of the Governors Photo Archives (NMHM/DCA), Negative No. 029030. 
[1931]) mentioned the use of earthenware pots in her early cookbooks, which are among the earliest and most celebrated cookbooks published on New Mexican cuisine. As she says, "the secret of tasty beans lies in cooking them just right...at low temperature and for a long time" (Cabeza de Baca Gilbert 2013 [1931]:21). Referencing a time-honored culinary tradition with indigenous roots, micaceous ceramics hearken back to memories of familiar New Mexican foods and the everyday tools and methods used to create them. The sensory-laden process of preparing a dish within a micaceous pot—soaking beans with water from an open cistern, practicing proper care and storage of the pot, slow heating and expert control of a fire, the sounds of simmering liquids and wooden tools against earthenware-were likely a calming force, reminiscent of past homes and routine behaviors.

\section{New Mexican Cuisine and Hispanic identity}

Cuisine refers not only to the edible outcomes of a food tradition but also to the process used to cook or produce the foods that people eat. Cooking processes are preordained by culinary identity, part of an "aesthetic code" (Crowther 2013:102) generating expectations about how a particular food should smell, taste, feel, and look following the chemical, physical, and hydration changes created by heat. Specific recipes or learned methods for cooking a particular dish create an idealized image or expectation about the sensory features of a finished food item (Crowther 2013:130). Crown (2000) describes cuisine as a cultural construct organizing how foods should be prepared and served, encoding anticipated flavor and texture outcomes defined by tradition.

The experience of diasporic displacement heightens this embodiment of memory in food or food-related items, producing "gustatory nostalgia" (Holtzman 2006:367) defined by a sensual recall of past food experiences in the homeland (Petridou 2001). For example, a Hispanic New Mexican woman named Cesaria Gallegos interviewed by the Works Progress Administration Federal Writers' Project in 1940 wistfully assigned an old national identity to her beans, stating that "there is no food como la Mexicana frijoles," while lamenting the loss of "the food they used to eat" (Rebolledo et al. 2000:7). For the first generation of women at Los Ojitos, preparing and serving beans in traditional micaceous pots would have imbued their new homes on the Middle Pecos with "the smells and tastes of a lost homeland" (Holtzman 2006:367).

In subsequent decades characterized in part by the experience of social and political discrimination by Anglos, maintenance of these pots and culinary traditions may have taken on an added layer of significance (Clark 2005, 2011). As Anglos within and outside of New Mexico disparaged Mexican culture and pushed for their cultural assimilation and Americanization (Deutsch 1987:111-112), the women at Los Ojitos might have chosen to maintain certain New Mexican culinary traditions as a way of claiming and celebrating their cultural heritage. In her study of Mexican women who experienced similar discrimination after immigrating to New Mexico in the early twentieth century, Raquel Rubio-Goldsmith (1998) observed that these women responded not by assimilating and eliminating or minimizing their traditional cultural practices but by recommitting to them. In response to the hostility surrounding them, these twentieth-century Norteñas built and planted traditional gardens outside of their homes, and inside, "they maintained their worship of God, the proper food, and the proper care of family" (Rubio-Goldsmith 1998:283). In the same way, the maintenance 
of micaceous pottery and associated culinary practices at Los Ojitos might have been a conscious and deliberate reaction by some village women to the cultural prejudice of neighboring Anglo-Americans.

Micaceous ceramic vessels at Los Ojitos, as part of the last generation of pots produced and traded through traditional means in northern New Mexico, represent material traces of the Hispanic homeland as it changed under the American regime. The loss of familiar tools that previously had been easily procured forced women to curate micaceous ceramics until they broke, and, once broken, to adapt to American-produced substitutes like enamel pots or cast iron pans with a new suite of cooking techniques (Fig. 7). Another New Mexican cookbook written in 1939 by Cleofas M. Jaramillo specifies using earthen pots for slow-cooking several dishes though, interestingly, recommends using a "white enameled pot or new tin coffee can" (Jaramillo 2008:6) for cooking dry beans.

Another common lament from the mid-twentieth century about beans burned in castiron pans or enamel pots may speak to a generation of women adapting to this new technology. Nasario García (2001:36) tells a story of his grandmother warning him not to marry "a girl who burns the beans," inspired by a local woman who often plagued her community with the pervading smell of burning frijoles. While mass-produced American cookware may be adequate to the task of cooking traditional New Mexican cuisine, the mastery of new cooking tools often involves an uncomfortable learning

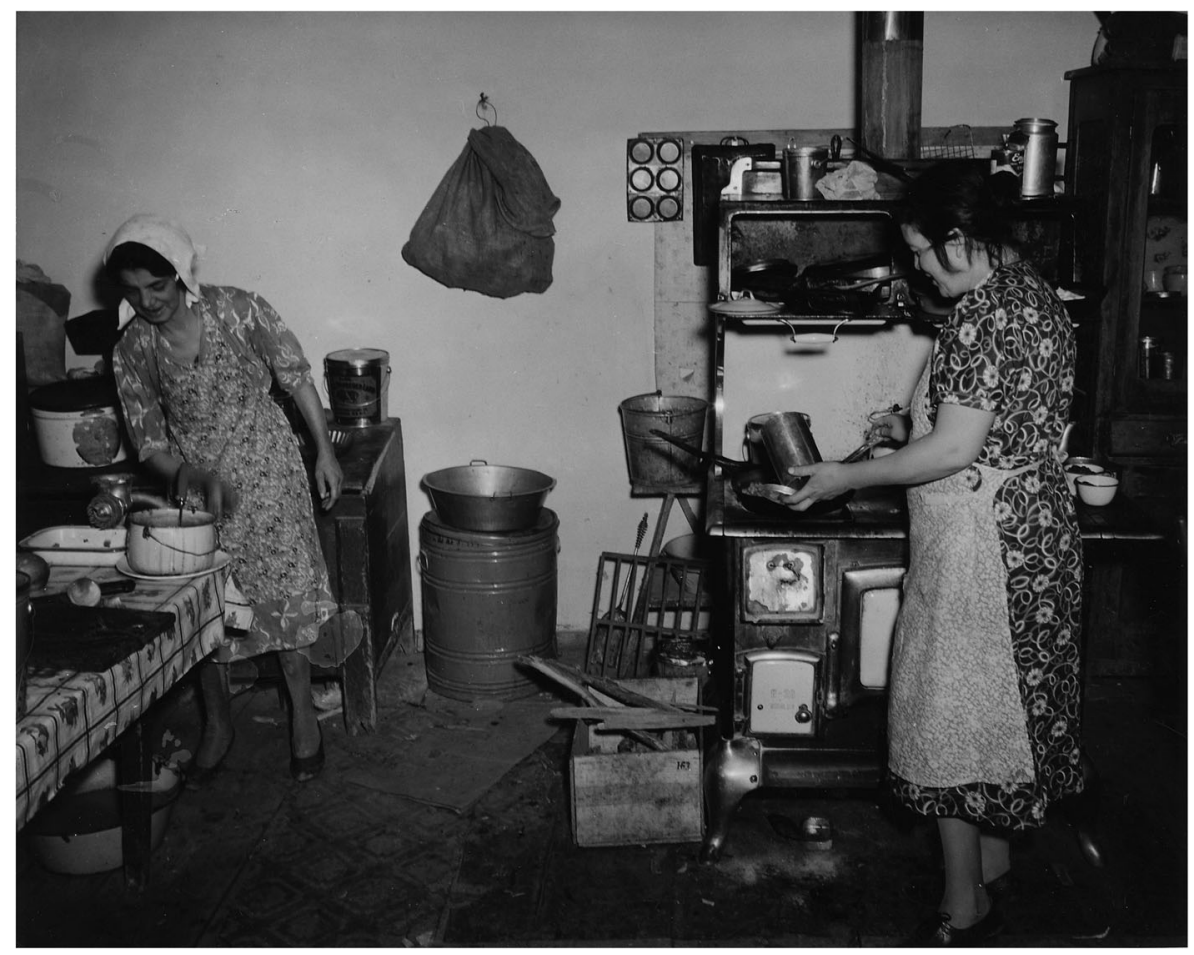

Fig. 7 Kitchen scene from El Cerrito, San Miguel County, New Mexico taken in 1941, featuring enamelware cooking pots and a wood-burning stove. Photograph by Irving Rusinow. Courtesy National Archives, Photo No. 80-G-37830. 
curve. More importantly, no metal pot can impart the same earthy flavor as the traditional micaceous bean pot. This forces the cook to adjust to a new definition of her own cooking prowess, and her personal and familial cuisine suffered from a new lack of traditional, expected flavor.

Archaeological evidence recovered at Los Ojitos suggests both maintenance of traditional New Mexican cuisine and adoption of American foods and food technologies. The women of Los Ojitos shifted away from the traditional practices of drying meat and plant foods, avidly adopting canning technologies as a replacement, and used store-bought canned goods such as lard and baking powder. Industrial tableware and kitchenware imported from the eastern United States, including yellowware mixing bowls, enamelware, fancy porcelain, and crockery fragments, were far more plentiful than micaceous ceramics at Los Ojitos (Jenks et al. 2017:217). Plates, utensils, and additional decorated tableware suggest a shift from traditional communal serving of stews to preparation and individual service of drier foods (Jenks et al. 2017:218). However, evidence of household-level butchering of cattle and sheep/goats at Los Ojitos suggests a continued preference for stew cuts (Jenks et al. 2017), which were likely prepared in traditional micaceous vessels. Overall, the assemblage suggests adoption of American food technology alongside preservation of traditional New Mexican ingredients, with the use of historical micaceous ceramic cookware as a significant material outlier.

The relative rarity of these ceramics among new tools and tableware would have made them stand out in kitchens at Los Ojitos, making explicit their inherent significance as touchpoints for cultural identity. As Naum (2012:110-111) remarks in the case of Baltic pottery in Scandinavia, "Displacement constituted a viable context for such 'revealing'... [of] vessels as silent reminders of the homes they had left behind, a material element inseparably related to their identity as immigrants." As literal pieces of the homeland imbued with memories of past meals, these everyday utilitarian pots conveyed old, earthy flavors to new landscapes, reinforcing continuity through the performance of culinary traditions. Micaceous ceramic vessels used to cook beans and stews represent both the maintenance of a traditional New Mexican culinary practice and a prized, durable artifact category. Traditional food preparation methods and the objects used to replicate them were passed down between generations of Hispanic women, enabling them to provide their families with well-prepared, nourishing staple foods just as their ancestors and relatives had done for centuries.

\section{Performing Family through Inherited Objects}

Hispanic women were traditionally responsible for procuring and storing all the necessities for a well-appointed kitchen, including ceramic cookware and tableware. When heirlooms are inherited tools meant to be used, such as ceramics associated with food preparation, they communicate strong expectations between female relatives about "productivity and social re-productivity" (Lillios 1999:237), about the right ways of cooking and the right kinds of foods to eat. Individual or familial techniques elaborate on standardized culinary forms, injecting personal preference, skill, and experience into what appears on the kitchen table. Culinary practices provide intergenerational ties to traditional Hispanic New Mexican practices while emphasizing women's responsibility and authority in sustaining their families. Micaceous pots were fundamental to 
supporting new households in far-flung places, especially when removed from everyday interaction with relatives and when faced with the social, emotional, and economic challenges of moving to a new place as a newly marginalized group.

In his study of Hispanic pottery traditions, Charles Carrillo (1997) routinely encountered Hispanic families living in the Upper Pecos River Valley who owned 80100 -year-old micaceous pots, often passed down to them by older female relatives. In one example, "Mrs. Trujillo used a micaceous bean pot that she had inherited from her mother until the bottom wore through in the 1940s. Unable to acquire a new pot, she began using a metal pot for her cooking" (Carrillo 1997:79). Several of Carrillo's informants produced late nineteenth- and early twentieth-century curated micaceous bean pots attributed to both Hispanic and Jicarilla Apache producers, while other ceramic types of similar temporal range and utilitarian character were not encountered. This speaks to the possible durability and longevity of micaceous ceramics, but also suggests a desire to preserve these precious and value-laden ceramics inherited from female relatives.

In a diasporic context, the meanings embodied by heirlooms can be heightened by feelings of displacement, fragmentation, and loss. As in Rubio-Goldsmith's (1998) case study of Mexican women who migrated to the United States, heirlooms often functioned as reminders of past relationships and ways to maintain and perform kinship over space and time. As objects used primarily by women, who often take on "the role of valuing and organizing passed on items, and the emotional forms of labor this entails" (Holmes 2018:15), micaceous ceramics link both collective ancestral histories and individual intergenerational relationships in a single everyday object. "[T]hese material affinities are heightened through objects put to use; as engaging objects in practice reveals how materiality and relationality are folded and layered together within the sensory and material qualities of objects" (Holmes 2018:15).

Using micaceous ceramics invoked shared memories of cooking together in a lovedone's distant kitchen, rife with associations of familiar smells and sounds, hearty nourishment, and comforting warmth. In this way, these curated artifacts embodied memories and emotions associated with family members, providing a way to interact with a relative and maintain a social relationship by proxy, transcending the barriers caused by migration, death, and the passage of time. Seasoned with a historical residue of past meals and memories, micaceous pots provided a way to make food the right way with tastes and smells remembered from childhood. The material qualities of micaceous pots and their sentimental value contribute to their longevity and persistence in Hispanic New Mexican sites many decades after their manufacture.

\section{Broader Implications}

In times of stress, migration, or disenfranchisement, certain curated artifacts and the processes involved with their use become salient points of contact with past sensations and memories, cultural identity, and familial relationships. This case study involves a longstanding Indigenous technology-micaceous cookpots - adopted as traditional tools for the production of Hispanic New Mexican cuisine during the Spanish and Mexican periods. In a new spatial and social context, situated on the Middle Pecos River in the Hispano-Anglo borderland, these micaceous pots became rare and 
irreplaceable due to American economic and social disruption. These curated cooking tools became vessels for memories of past meals and sensory experiences unique to the Hispanic homeland and its culinary traditions, as well as a means of preserving and honoring familial relationships despite separation.

Rudolfo Anaya (1999 [1972]), the late author of the classic novel Bless Me, Ultima, grew up in a small village on the Pecos River in the 1940s - a place not far from and very similar to Los Ojitos near the end of its occupation. In his essay "Querencia, Mi Patria Chica," written as a foreword to the edited volume Querencia: Reflections on the New Mexico Homeland, Anaya (2020:xv) describes querencia as a "love of home, love of place," encapsulating a narrative about one's origins centered on home, family, and heritage, and a physical and spiritual place to return to as a source of safety and strength. He extends querencia explicitly to the Hispanic New Mexican diaspora and to everyone on the move, displaced, deployed, or incarcerated, writing that "one can make querencia wherever one lives" (Anaya 2020:xviii). As an element of emotional life that can be deliberately constructed, especially in times of upheaval, querencia offers an understanding of one's belonging in multiscalar familial, social, and historical landscapes. When creating a new life and new home in a new place, decisions to keep and maintain specific artifacts or items reinforce querencia as it lives in material objects.

In our experience, family and friends reminisce about cast iron pans the same way Hispanic New Mexicans reminisced about micaceous bean pots-food prepared with cast iron just tastes better, and the pot's seasoning, by definition, is a resilient historic deposit that imbues foods with inherited flavors. This clued us in to a deep-rooted, nearuniversal attachment to certain traditional "comfort foods," or the tools and processes used to create them, especially potent in times of stress or change. Drafting this article became urgent to us in the early days of the COVID-19 pandemic as we found ways to cope with the new-found realities of stay-at-home orders and socioeconomic upheaval. Ubiquitous emotional regulation responses to these stresses involved a return to traditional means of sourcing and preparing food items, such as baking sourdough bread, planting a victory garden, or canning produce.

Again, in times of stress or disruption to everyday life, we turn to older methods for practical reasons - to eke out subsistence from forgotten pantry items when grocery trips are ill-advised or when a future paycheck is not guaranteed - but also to re-enact a comforting, prosaic ritual resurrected from ancestral kitchens, real or idealized. In her Sapiens article "Can Archaeology Explain the Bread Baking Craze?," Robyn Cutright (2020) suggests that "[p]eriods of stress and change can prompt people to hold on to their diets and culinary traditions... as a way of buffering uncertainty and upheaval." The act of creating a dish through traditional means can provide a few moments of individual control over a routine process as the world spins out of control, "preserv[ing] a sense of stability and social cohesion even as life outside the home change[s]" (Cutright 2020). We find comfort in older technologies and processes because they sustained our ancestors physically and emotionally for centuries, and in many ways, similarly self-determined, self-affirming, subsistence-level culinary activities have disappeared from our lives with economic and technological changes.

In the context of historical archaeology, this may be one of many potential motivations behind the curation of artifacts beyond their typical lifespan and expected spatial range. The last four centuries of colonialism resulted in voluntary or involuntary 
movement of populations across the globe, just as the last two centuries of rapid technological change and globalization generated new tools and goods to be adopted readily or reluctantly. Most sites studied by historical archaeologists hold material evidence of curation decision-making by relocated or displaced people who experienced stress, social isolation, or discrimination in their new environments. James Deetz (1996:26), when faced with a mean ceramic date at the Parting Ways site pre-dating the actual occupation by nearly thirty years, suggested that the high-status assemblage might have been hand-me-downs from elite neighbors to the ex-slave occupants of the site. He urged historical archaeologists to investigate such discrepancies since a "search for the explanation might well result in a better understanding of the material in cultural or behavioral terms" (Deetz 1996:27).

Reconsidering seemingly anachronistic items pre-dating the occupation of an archaeological site can reveal significant social and emotional realities of the people who lived there. A problematic, anachronistic artifact presents an opportunity for reinterpretation from a social and emotional lens to explore how people came to define themselves in new environments. What do people choose to maintain or discard? What do people hold on to, and why? These decisions, we suggest, are based not only on practical purposes, but can potentially stem from lived social, emotional, and cultural realities often heightened and highlighted by change and disruption. In the case of Los Ojitos, women may have maintained micaceous bean pots for both their functional preeminence in the preparation of New Mexican cuisine and for their embodiment of querencia, made poignant by disconnection from traditional homelands and kin.

Acknowledgments The authors would like to thank the descendants of the Los Ojitos community, the students and staff who participated in fieldwork at Los Ojitos, and archaeologists Jeffery Hanson and Mark Hungerford at the Bureau of Reclamation's Albuquerque Office who permitted and supported this and previous projects. Particular thanks are given to Ernesto Chavez, who shared his memories of Los Ojitos in an oral history interview with Tara del Fierro Duran, as well as Clarence Cruz (Ohkay Owingeh) and Martha Romero (Nambé Pueblo), who shared their artistic expertise and practical knowledge of micaceous ceramics. We dedicate this article to Mark Hungerford, who steadfastly supported this site, our students, and members of the descendant community. May he rest in peace.

\section{References}

Abel, A. H. (1915). The Official Correspondence of James S. Calhoun. Office of Indian Affairs, Washington, DC.

Abel, A. H. (1916). The journal of John Greiner. Old Santa Fe: A Magazine of History, Archaeology, Genealogy and Biography 3(11):189-243.

Adams, W. (2003). Dating historical sites: the importance of understanding time lag in the acquisition, curation, use, and disposal of artifacts. Historical Archaeology 37(2):38-64.

Anaya, R. (1999 [1972]). Bless Me, Ultima. Warner, New York.

Anaya, R. (2020). Querencia: mi patria chica. In Fonseca-Chávez, V., Romero, L., and Herrera, S. R. (eds.), Querencia: Reflections on the New Mexico Homeland, University of New Mexico Press, Albuquerque, pp. xiii-xxii.

Anderson, D. (1999). All That Glitters: The Emergence of Native American Micaceous Art Pottery in Northern New Mexico. School of American Research Press, Santa Fe, NM.

Appadurai, A. (1986). Introduction: commodities and the politics of value. In Appadurai, A. (ed.), The Social Life of Things: Commodities in Cultural Perspective, Cambridge University Press, Cambridge, pp. 3-63.

Bender, A. B. (1974). A Study of the Jicarilla Apache Indians 1846-1887. Garland, New York. 
Bourdieu, P. (1973). The Berber house. In Douglas, M. (ed.), Rules and Meanings: The Anthropology of Everyday Knowledge, Penguin, Harmondsworth, pp. 98-110.

Bourdieu, P. (1977). Outline of a Theory of Practice. Cambridge University Press, Cambridge.

Cabeza de Baca Gilbert, F. (1982 [1949]). The Good Life: New Mexico Traditions and Food. Museum of New Mexico Press, Santa Fe.

Cabeza de Baca Gilbert, F. (2013 [1931]). Historic Cookery. Gibbs Smith, Layton, Utah.

Carrillo, C. M. (1997). Hispanic New Mexican Pottery: Evidence of Craft Specialization 1790-1890. LPD Press, Albuquerque.

Clark, B. J. (2005). Lived ethnicity: archaeology and identity in Mexicano America. World Archaeology 37(3):440-452.

Clark, B. J. (2011). On the Edge of Purgatory: An Archaeology of Place in Hispanic Colorado. University of Nebraska Press, Lincoln, Nebraska.

Clifford, J. (1994). Diasporas. Cultural Anthropology 9(3):302-338.

Cowell, S. (2018). Historic Micaceous Ceramics and Cuisine at Los Ojitos, New Mexico. Master's thesis, New Mexico State University, Las Cruces.

Crown, P. L. (2000). Women's role in changing cuisine. In Crown, P. L. (ed.), Women and Men in the Prehispanic Southwest: Labor, Power, and Prestige, School of American Research, Santa Fe, NM, pp. 221-266.

Crowther, G. (2013). Eating Culture: An Anthropological Guide to Food. University of Toronto Press, Toronto.

Cutright, R. (2020). Can archaeology explain the bread baking craze? Sapiens. Electronic article, https://www. sapiens.org/archaeology/can-archaeology-explain-the-bread-baking-craze/, accessed July 12, 2020.

Davis, W. W. H. (1982 [1857]). El Gringo: New Mexico and Her People. University of Nebraska Press, Lincoln.

Deetz, J. (1996). In Small Things Forgotten: An Archaeology of Early American Life. Anchor, New York.

del Fierro Duran, T. (2018). "Aguaculture”: Hispano Water Management along the Rio Pecos. M.A. thesis, New Mexico State University, Las Cruces.

Deutsch, S. (1987). No Separate Refuge: Culture, Class, and Gender on an Anglo-Hispanic Frontier in the American Southwest, 1880-1940. Oxford University Press, New York.

Ebright, M. (1994). Land Grants and Lawsuits in Northern New Mexico. University of New Mexico Press, Albuquerque.

Eiselt, B. S. (2005). A brief guide to the identification of historic Micaceous Ceramics of the northern Rio Grande: including types attributed to Hispanic, Northern Tewa, Northern Tiwa, and Jicarilla Apache Potters. Manuscript in possession of the author. Electronic resource, http:/www.seiselt.googlepages.com/ Guide.pdf, accessed October 2009.

Eiselt, B. S. and Darling, J. A. (2012). Vecino economics: gendered economy and micaceous pottery consumption in nineteenth-century northern New Mexico. American Antiquity 77(3):424-448.

Eiselt, B. S. and Ford, R. I. (2007). Sangre de Cristo micaceous clays: geochemical indices for source and raw material distribution, past and present. KIVA: The Journal of Southwestern Anthropology and History 73(2):219-238.

Fogelin, L. (2019). An Unauthorized Companion to American Archaeological Theory. Electronic resource, https://arizona.academia.edu/LarsFogelin, accessed November 2019.

Fonseca-Chávez, V., Romero, L., and Herrera, S. R. (eds.) (2020). Querencia: Reflections on the New Mexico Homeland. University of New Mexico Press, Albuquerque.

Foster, G. M. (1960). Life-expectancy of utilitarian pottery in Tzintzuntzan, Michoacan. American Antiquity 25(4):606-609.

Foxhall, L. (2012). Material values: emotion and materiality in ancient Greece. In Chaniotis, A. and Ducrey, P. (eds.), The Role of Emotions in Classical Antiquity, Steiner Verlag, Stuttgarted.

Frank, R. H. (2000). From Settler to Citizen: New Mexican Economic Development and the Creation of Vecino Society, 1750-1820. University of California Press, Berkeley.

García, N. (2001). Brujas, Bultos, y Brasas: Tales of Witchcraft and the Supernatural in the Pecos Valley. Western Edge Press, Santa Fe, NM.

Gómez, L. E. (2007). Manifest Destinies: The Making of the Mexican American Race. New York University Press, New York.

Holmes, H. (2018). Material affinities: "doing" family through the practices of passing on. Sociology 53(1): $174-191$.

Holtzman, J. D. (2006). Food and memory. Annual Review of Anthropology 35:361-378.

Jaramillo, C. M. (2008). New Mexico Tasty Recipes, with Additional Materials on Traditional Hispano Food. Gibbs Smith, Layton, Utah. 
Jenks, K. L., Giomi, E., Smith, J., Goodson, M., Burchell, R., and Miller, A. (2017). Final Report of Archaeological Fieldwork and Documentation at Los Ojitos (LA 98907), Guadalupe County, New Mexico. Bureau of Reclamation, Upper Colorado Region, Albuquerque Office, Albuquerque, NM.

Jenks, K. L. (2019). Prehistoric rock art and historic "graffiti." In Brown, E. J., Barbour, M. J., and Head, G. N. (eds.), Scholar of the City Different: Papers in Honor of Cordelia Thomas Snow. Archaeological Society of New Mexico, Santa Fe, pp. 109-122.

Kopytoff, I. (1986). The cultural biography of things: commoditization as process. In Appadurai, A. (ed.), The Social Life of Things: Commodities in Cultural Perspective, Cambridge University Press, Cambridge, pp. 64-91.

Lillios, K. T. (1999). Objects of memory: the ethnography and archaeology of heirlooms. Journal of Archaeological Method and Theory 6:235-262.

Mauss, M. (1954). The Gift: Forms and Functions of Exchange in Archaic Societies. Free Press, Glencoe, IL.

Meinig, D. W. (1971). Southwest: Three Peoples in Geographical Change 1600-1970. Oxford University Press, New York.

Miller, D. (2005). Materiality. Duke University Press, Durham, NC.

Miller, D. (2008). The Comfort of Things. Polity, Cambridge.

Mora, A. P. (2011). Border Dilemmas: Racial and National Uncertainties in New Mexico, 1848-1912. Duke University Press, Durham, NC.

Moussouri, T. and Vomvyla, E. (2015). Conversations about home, community, and identity. Archaeology International 18:97-112.

Naum, M. (2012). Ambiguous pots: everyday practice, migration, and materiality: the case of medieval Baltic ware on the island of Bornholm (Denmark). Journal of Social Archaeology 12(1):92-119.

Nieto-Phillips, J. M. (2004). The Language of Blood: The Making of Spanish-American Identity in New Mexico, 1880s-1930s. University of New Mexico Press, Albuquerque.

Nostrand, R. L. (1992). The Hispano Homeland. University of Oklahoma Press, Norman.

O'Mack, S. (2006). Draft Nomination to the National Register of Historic Places for the Los Ojitos Archaeological District. Bureau of Reclamation, Albuquerque Office, Albuquerque, NM.

Parkin, D. (1999). Mementoes as transitional objects in human displacement. Journal of Material Culture 4(3):303-320.

Petridou, E. (2001). The taste of home. In Miller, D. (ed.), Home Possessions: Material Culture Behind Closed Doors, Berg, Oxford, pp. 87-104.

Rebolledo, T. D., Márquez, M. T., and United States Work Projects Administration (N.M.). (2000). Women's Tales from the New Mexico WPA: La Diabla a Pie. Arte Público Press, Houston, TX.

Rodríguez, S. (1992). The Hispano homeland debate revisited. Perspectives in Mexican American Studies 3: 95-116.

Rodríguez, S. (2017). History, memory, and Querencia. In Mills, B. J. and Fowles, S. (eds.), The Oxford Handbook of Southwest Archaeology, Oxford University Press, New York, pp. 193-205.

Romero, M. (2017). Cooking in Micaceous Pottery with Martha Romero (Nambe). Lecture presented November 18, 2017 at the Indian Pueblo Store (formerly Shumakolowa Native Arts), Albuquerque, NM.

Rubio-Goldsmith, R. (1994). Seasons, seeds, and souls: Mexican women gardening in American Mesilla, 1900-1940. In Fowler-Salamini, H. and Vaughan, M. K. (eds.), Women of the Mexican Countryside, 1850-1990, University of Arizona Press, Tucson, pp. 140-158.

Rubio-Goldsmith, R. (1998). Civilizations, Barbarism, and Norteña Gardens. University of Arizona Press, Tucson.

South, S. (1977). Method and Theory in Historical Archaeology. Academic Press, New York.

Tarlow, S. (2012). The archaeology of emotion and affect. Annual Review of Anthropology 41:169-185.

Tolia-Kelly, D. P. (2004). Location processes of identification: studying the precipitates of re-memory through artefacts in the British Asian home. Transactions of the Institute of British Geographers 29(3):314-329.

Van Ness, J. R. (1991). Hispanos in Northern New Mexico: Development of Corporate Community and Multicommunity. AMS Press, New York.

Warren, A. H. (1981). The micaceous pottery of the Rio Grande. In Schroeder, A. H. (ed.), Collected Papers in Honor of Erik Kellerman Reed, Museum of New Mexico Press, Santa Fe, pp. 149-165. 
West, S. M. (1992). Temper, Thermal Shock and Cooking Pots: A Study of Tempering Materials and Their Physical Significance in Prehistoric and Traditional Cooking Pottery. Master's thesis, University of Arizona, Tucson.

Williamson, C. (2006). Dating the domestic ceramics and pipe smoking related artifacts from Casselden Place, Melbourne, Australia. International Journal of Historical Archaeology 10(4):329-341.

Publisher's Note Springer Nature remains neutral with regard to jurisdictional claims in published maps and institutional affiliations. 